\title{
On the Library Service Process Reengineering under New Media Environment
}

\author{
Yinhong Liu \\ Library of Wuhan University of Technology \\ Wuhan Hubei, 430063
}

\begin{abstract}
Driven by the new media technology, the library is developing from traditional collections mode to digitalization and intellectualization direction. Users' needs and behaviors become more diversified. The library is facing an embarrassing situation so that traditional service business is declining, while digital information services are difficult to meet users' needs. Therefore, this paper summarizes the new library services, analyses the necessity and importance of Library Service Process Reengineering under the new media environment. Based on this, it constructs a new framework of library service process under the new media environment so that it can better provide new services for users and promote the sustainable development of the library.
\end{abstract}

Keywords—new media; library; service process; reengineering

\section{INTRODUCTION}

With the development of information technology, especially Internet plus and mobile communication technology, the environments of various service are constantly upgraded. As an information intensive industry, library services become digital and smart increasingly. In order to make full use of knowledge and information, reduce the cost of the library and meet the needs of users, the library service needs to be constantly optimized and innovated with the help of more advanced information technology. The process will also be different from the traditional service, which must be restructured and reformed accordingly to provide more people with efficient and high-quality service. In this case, it is of practical significance to discuss the new ideas of information technology and new media technology in library service reengineering.

\section{OVERVIEW OF LIBRARY SERVICES IN THE NEW MEDIA ENVIRONMENT}

With another breakthrough in information technology, we have entered a new era of information - new media era. New media supported by information technology has rapidly changed the way of information dissemination and knowledge sharing. As an institution to collect, organize, store, transform and disseminate information and knowledge, library is significantly affected by the change of new media technology. "The library is a growing organism," said Ranganathan, a famous Indian library scientist [1]. The development of library has evolved from traditional library to digital library and compound library, ushering into smart library. With the change of its specific form, the content and process of its services are constantly adjusted and transformed. At present, in addition to various users service sectors involving traditional library and all kinds of information services based on network environment, library also adds some extension services, such as: mobile/cell phone library, Weibo, WeChat service and user push notification service and IC room service based on location.

\section{THE NECESSITY OF LIBRARY SERVICE PROCESS}

\section{REENGINEERING UNDER THE NEW MEDIA ENVIRONMENT}

With the continuous development of the information society, the influence of new media is growing. China has 802 million Internet users, of which 98.3 percent are mobile users. News apps and various social media have become the first source of information for many cadres and the masses, especially young people, and everyone may become the source of information. Some people say that it was "the people who look for information" in the past and now it is "the information who seek for people". Therefore, it is an urgent task for us to promote the integrative development of media and the construction of omnimedia [2]. Digital reading has become one of the main ways for people to read. On April 18th 2018, Chinese Academy of Press and Publication released the results of the 15th survey on national reading in Beijing. According to the survey data, the comprehensive reading rate in all kinds of media, including books, newspapers and digital publications, increased to $80.3 \%$ in 2017 compared with $79.9 \%$ in 2016. The contact rate of digital reading methods (online reading, mobile reading, e-reader reading, Pad reading, etc.) was $73.0 \%$ with an increase of 4.8 percentage compared with $68.2 \%$ in 2016 . From the perspective of people's exposure time to different media, mobile phones and the Internet have become the main part of daily media exposure for Chinese adults, and the reading time of printed books and periodicals has also increased. Meanwhile, audio reading has become a new growth point in national reading. In 2017 , more than $20 \%$ of our citizens have the habit of listening to books. Mobile audio APPs has become the mainstream choice for people to listen to books [3]. From paper reading to online reading, from online reading to mobile reading, people's reading habits and media are constantly changing. With the deepening of information technology and Internet application, library services need to be adjusted in time to provide better services for users.

Against the background of the new media, mobile phone, tablet and other mobile terminals gradually become new information media. People will increasingly receive and use information through the mobile information platform and the 
library is no longer restricted by time and space and reading media. Under the influence of such an environment, the reform of library service process will attract more attention from users. Domestic and foreign library scholars have made continuous research and exploration. The $77^{\text {th }}$ IFLA annual meeting was held from August 13rd to 18th, 2011. Allen Tise, the president of IFLA World Library and Information Congress, pointed out in the opening ceremony that now the library is undergoing a radical change from paper collection to electronic collection, which requires the library to be redefined and rebuilt. The annual meeting focuses on issues relating to library restructuring, such as Rethink, Redefining, Restaffing, restructuring and Renewing [4]. One of the themes of the 2012 annual meeting of Library Society of China is the transformation of library service and management in the information society, among which the topic of library service process reengineering is mentioned [5]. However, a large number of scholars focus on the research on the library business reengineering [6], the causes of library business process reengineering [7], the library business process reengineering in institutions of high learning under the digital environment [8], library business process innovation service [9] and other aspects, mainly focusing on the study of library business process reengineering. However, new media technology has brought impacts and challenges to libraries. In this context, it requires libraries to look for new opportunities for development in a deeper level, explore new service modes with new ways of thinking and sort out and research the content and direction of service process reengineering in time under the new media environment.

\section{LiBRARY SERVICE PROCESS REENGINEERING UNDER THE NEW MEDIA ENVIRONMENT}

The application of new media and its deep integration have a broad and profound impact on the entire knowledge ecosystem. Digital publishing overcomes the limitations of print media and provides authors with a richer way of knowledge expression. The use of the Internet makes information spread more quickly and widely. Mobile terminal enables people to obtain knowledge and information in a broader manner. Social networks provide a platform for users with the same interests and needs to communicate. The application of visualization technology makes the presentation of knowledge and information more vivid and threedimensional. Knowledge service system characterized by adaptive human-computer gives users perfect experience. The development of media has brought about great changes to the dissemination of knowledge and information. However, unfortunately it is not satisfying for libraries in the construction of information resources, the introduction of new media technology, service content and methods and management models. Libraries are facing the embarrassed situation where business volume of traditional service declines unceasingly, but the digital information service actually is difficult to satisfy the users' demand. In the face of new characteristics of resource type, communication mode and users' information behavior, libraries must carry out a comprehensive transformation and even upgrade, and improve and enhance the resource construction, knowledge service and management.
From its emergence to the modern times, due to the development and application of information technology, the library has undergone four major revolutionary evolutions, namely, the transformation from the traditional library, digital library and compound library to the smart library. With each evolution, great new changes have taken place in resources, services, technologies and users, and libraries have made qualitative leaps in terms of the breadth and depth of service. The transformation is achieved in smart library from serviceoriented information provider to user-experience-oriented information provider, from multimedia information to multimedia integrative information, cross-border integration of information resources, cloud storage of information resources, and integration of information services. In order to adapt to this change, it is necessary to innovate its service mode and establish service process, especially to meet the information needs of new users. It should take the change of users' needs into consideration in the new media environment, set service projects and modes according to their needs and actively provide users with personalized and efficient knowledge and information services. Due to the close and inseparable relationship between users and libraries (see fig. 1), libraries must optimize and restructure their service processes based on users' behavior. From the perspective of users, only by improving and optimizing the service process under the new environment, restructuring the process management, enhancing the service quality, increasing the service efficiency, reducing the service cost and constantly improving the users' satisfaction can the library play a greater role in the new media era and fully reflect its value [10].

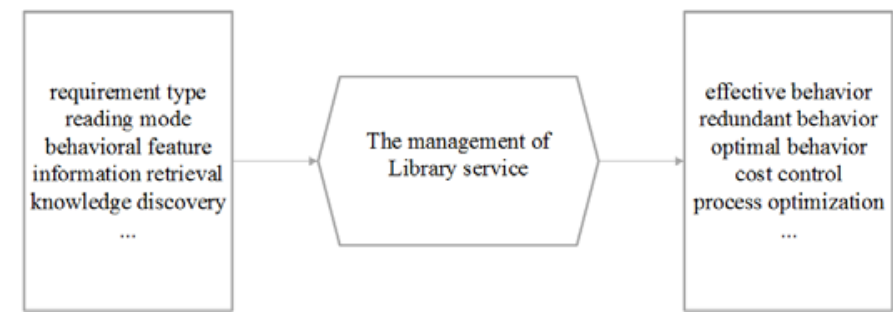

Fig. 1. Correspondence diagram of user behavior and library service flow

The application of new media technology stimulates users' new demands on libraries and brings new challenges to libraries. It is another important task for the library to make full use of new media technology, combine the library with new media, lead the new mode of information service, expand new channels of information service, innovate the process of information service and make the library service meet users' needs in a more efficiently and high-quality manner. Service process reengineering does not fully deny the original process and pattern. Instead, it adds creative ideas and introduces innovative projects or models for the original service process while emphasizing the new changes in the aspects of the demand, technology and service quality in order to optimize or restructure service process to meet the new users' requirements. In the new media era, the service process reengineering of smart library centers on users, which reengineer the process and innovate services by integrating information resources, technical equipment and users to provide users with all-round smart knowledge and information services. This includes not 
only the redesign and reengineering of traditional library services, but also new application in emerging services. Therefore, based on users' demand and taking their satisfaction as ultimate goal, the following library service flow diagram (fig. 2) is built.

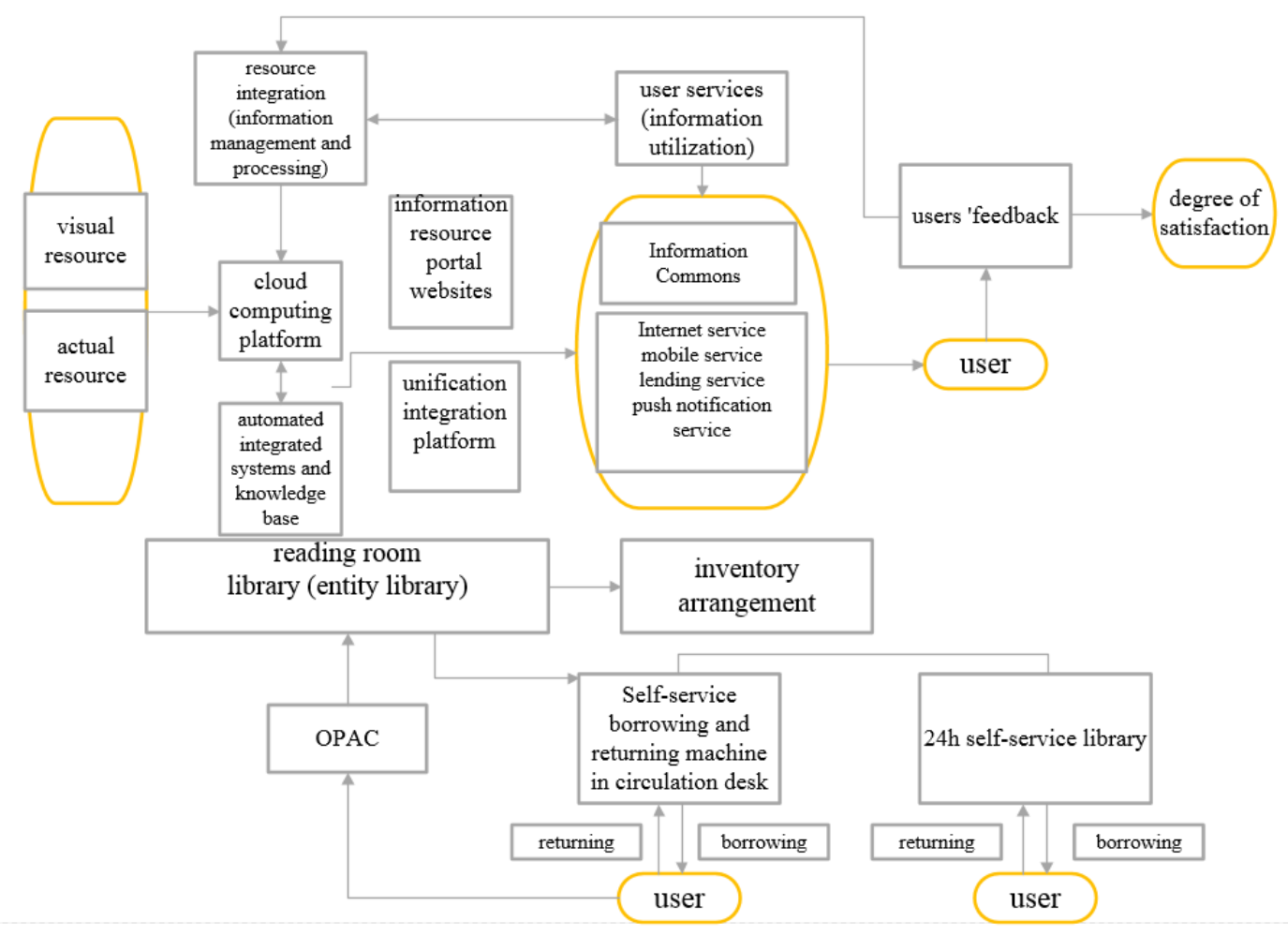

Fig. 2. Flow diagram of library new media service

\section{A. Resource restructuring}

In the era of new media, information is changing including its carrier form, expression form, and mode of transmission, service mode and behavior of users to use the library. The library information resource construction is gradually transforming towards digital information resource. At present the purchase expense of most of the library digital information resources is higher than that of paper documents. Therefore, while optimizing printed library's service, libraries should focus on the construction of and sorting out digital information resources, widely use all kinds of media in libraries with the aid of new media, emphasize diversified channels to spread information, strengthen the construction of the virtual space, change librarian role, pay close attention to the change of users' needs, change service mode and method, transform the library work from resources construction to service provider and gradually enhance the level of smart technology in order to bring more perfect use of experience for the user and provide users with diversified, personalized, intelligent, efficient, lowcost knowledge and information services by taking customers' satisfaction as the goal.

\section{B. Information resource portal and service integration platform}

Faced with a flood of resources and information, users not only need to learn how to identify and select appropriate resources, but also how to analyze, operate and evaluate various paper and digital resources. Libraries use Internet integration platform such as cloud computing and big data to provide users with desktop-oriented service represented by portal websites and mobile services represented by Weibo, WeChat, APPs and so on. Additionally, libraries should become such a space as provides users with tools and methods required by scientific research of computer-based knowledge-Information Commons (referred to as IC). IC space mainly includes three aspects: physical space (traditional reference consultation provided by existing library implementation, lectures, training and other services), virtual space (information retrieval, acquisition and usage on the basis of digital collection, portal websites and multimedia software and online consulting services), cultural space (provide users with research and consulting, skills development and academic help, seminars, etc.), thus libraries can provide extension services from the circulation of traditional paper documents to scientific research data management and knowledge sharing. By sharing resources, personnel, technology and ideas, it not only makes effective use of the limited resource space of libraries, but also maximizes the efficiency of resource funds, reduces the cost, and provides users with one-stop integrated services.

\section{Putting users first}

Although libraries have been aware of the importance of users in their traditional information service, they do not center on users in real sense and still yet fully explore the needs and values of users. The library has entered the smart service period 
in the new media era, and the users' demand has shown a diversified trend. The service concept of "user-centered" should be implemented in a real way to fully confirm the status and value of users in the library. Libraries should emphasize user experience in new media service. Only by fully understanding users' real experience in the service can we actively adjust service strategy to effectively guarantee the central role of users.

\section{CONCLUSION}

To sum up, when providing new media service, libraries need to closely link with information resources, Internet technology, smart equipment, librarians, user requirements, etc. And it should give full play to the advantages of library collection, expand digital network resources, fully apply Internet technology and multimedia equipment into the information service, combine the ability of librarians with information literacy ability of users, strengthen their interaction in information and feedback, eliminate the barriers of information transmission and improve users' satisfaction, thus realizing organic and sustainable development of the library.

\section{REFERENCES}

[1] Ranganathan, Shiyali Ramamrita. The Five Laws of Library Science[M] Translated by Xia Yun. Beijing: Bibliographic Literature Publishing House, 1988:308. (In Chinese)

[2] Accelerating the Development of Media Integration and Constructing the Whole Media Communication Pattern.[EB/OL].[2019-0315].https://www.xuexi.cn/0af8e58a9ecff5a2d1c89181274206ed/e43e220 633a65f9b6d8b53712cba9caa.html (In Chinese)

[3] Release of the results of the 15th National Reading Survey[EB/OL].[2018-04-24] http://ex.cssn.cn/wx/wx_zjft/201804/t20180424_4211682.shtml (In Chinese)

[4] MAIJA BERNDTSON. "What and why libraries? "-looking at what libraries might look like and why we still need them now and into the future[EB/OL]. [2012-08-08].

http://conference.ifla.orQ/sites/defauldfiles/files/papers/ifla77/123berndtson-en.pdf.

[5] Notice for soliciting papers for Annual Conference of Chinese Library Society in 2012[EB/OL]. [2012-05-20]. http://www.Isc.org.cn/CN/News/2012-02/EnableSite ReadNews1131359171329148800.html(In Chinese)

[6] Zhu Q. Bie L.Q.. Restructuring Workflow and Organization of Peking University Library [J].Journal of Academic Library, 2016, 34(02):20-27. (In Chinese)

[7] Huang R. H.; Xu J.H.. Causes of Implementing Business Process Reengineering in Libraries [J].Library Tribune, 2009, 29(06):180-183. (In Chinese)

[8] Zhang Q.Research on Business Process Reengineering of University Library under Digital Environment [J].Ability And Wisdom, 2018(33):134. (In Chinese)

[9] Zhang Bilan. The Business Process Reconstruction of University Library Based on the Service Innovation J].,2018(01):35-39. (In Chinese)

[10] Cordes S. Process management for library multimedia development service[J]. Library Management, 2008, 29(3):185-198. 